\title{
Olive wastewater as an ecological fertiliser
}

\author{
Ali MeKki, Abdelhafidh DHouib, Fathi Aloui, Sami SAYAdI* \\ Laboratoire des bioprocédés, Centre de biotechnologie de Sfax, BP K, 3038 Sfax, Tunisia
}

(Accepted 25 November 2005)

\begin{abstract}
The effects of untreated and treated olive mill wastewater on seed germination, plant growth and soil fertility were studied. Tomato (Lycopersicon esculentum), chickpea (Cicer arietinum), bean (Vicia faba), wheat (Triticum durum) and barley (Hordeum vulgare) were tested for the germination index and growth in soil irrigated by olive mill wastewater. Lepidium sativum was used as the standard species for the germination index and phytotoxicity evaluation. We measured soil properties, crop growth, herbage biomass, leaf elongation and productivity. The results show beneficial effects using treated olive mill wastewater. The treated plants showed an improvement in seed biomass, spike number, plant growth, and a similar or even better dry productivity than plants irrigated with water, e.g. Hordeum vulgare $102 \%$, Triticum durum $105 \%$, Cicer arietinum $101 \%$ and Vicia faba $102 \%$. An increase in the germination index from $100 \%$ to $115 \%$ was observed. Soil organic matter, respiration and enzymatic activities were also enhanced by treated olive mill wastewater ferti-irrigation. However, even diluted 10 times, untreated olive mill wastewater inhibited the species germination, e.g. 1.2\% for Hordeum vulgare and 40\% for Cicer arietinum and Vicia faba, and plant growth (16-42.5\%). Leaf necrosis and low productivity were observed in crops ferti-irrigated by untreated olive mill wastewater.
\end{abstract}

olive mill wastewater / germination index / phytotoxicity / crop growth / soil fertility

\section{INTRODUCTION}

The olive oil extraction process produces huge amounts of liquid waste called olive mill wastewater (OMW). Large amounts of OMW are produced in the Mediterranean region, an area that accounts for $95 \%$ of the total olive oil production worldwide (Sayadi et al., 2000; Hytiris et al., 2004). The annual production of OMW in these countries reached 30 million cubic metres (D'Annibale et al., 2004). This waste contains an enormous supply of organic matter, chemical oxygen demand (COD) between 40 and $210 \mathrm{~g} \mathrm{dm}^{-3}$ and biochemical oxygen demand $\left(\mathrm{BOD}_{5}\right.$ ) between 10 and $150 \mathrm{~g} \mathrm{dm}^{-3}$ (Feria, 2000). The uncontrolled disposal of OMW may cause serious environmental pollution with unforeseeable effects on the soil-plant system in olive-producing areas (Capasso et al., 1992; Rana et al., 2003). Fortunately, some characteristics of this material are favourable for agriculture since this effluent is rich in organic matter, N, P, K and Mg (Casa et al., 2003; Rinaldi et al., 2003). Consequently, an increasing interest has been shown in spreading OMW on agricultural lands to recycle the organic matter and fertilise the soil. Indeed, research has found that this method of disposing of OMW constitutes a potential solution for this problem. In this perspective, several studies found a positive effect of OMW on soil fertility and crop growth (Vassilev et al., 1998; Casa et al., 2003; Cereti et al., 2004; Paredes et al., 1999, 2005). Furthermore, it was demonstrated that when incorporated or applied as a mulch, OMW could favourably affect the soil balance by reducing evapo-transpiration (Feria, 2000).
Rinaldi et al. (2003) indicated that OMW spreading does not result in heavy metal accumulation in the soil. Therefore, they considered that its environmental pollution risk was low. However, recent studies found that the addition of unprocessed OMW causes significant shifts in the structure and function of microbial communities which in turn influences the soil fertility (Cox et al., 1998; Sierra et al., 2001; Mekki et al., 2006). Moreno et al. (1987) warmed that OMW application causes serious environmental problems due to its antibacterial effects and its phytotoxicity. Therefore, research has not yet reached a consensus about the effects of this by-product of olive treatment. Hence, it seems imperative that further detailed studies be done.

For this purpose, this work, built on previous studies in the same laboratory (Dhouib et al., 2006; Mekki et al., 2006), attempted to assess the benefits of reusing treated OMW in ferti-irrigation. A comparison of its effects with those of the application of untreated OMW on seed germination, plant growth and soil fertility was undertaken.

\section{MATERIALS AND METHODS}

\subsection{Origin of olive mill wastewater}

The fresh olive mill wastewater was taken from a threephase discontinuous extraction factory located in Sfax, Tunisia.

* Corresponding author: sami.sayadi@cbs.rnrt.tn 


\subsection{Biological treatment of olive mill wastewater}

The treated olive mill wastewater was obtained with an integrated process based on aerobic fungal pre-treatment using Phanerochaete chrysosporium DSMZ 6909 followed by a decanting step, then anaerobic digestion (Sayadi and Ellouz, 1995).

\subsection{Plot distribution and crops cultivated}

The experiments were carried out in a field located in Sfax, Tunisia. The field was subdivided into different plots which were distributed according to the Latin square standard method (Dagnelie, 2003). 16 plots were irrigated with untreated olive mill wastewater at $100 \mathrm{~m}^{3} \mathrm{ha}^{-1}, 16$ plots were irrigated with treated olive mill wastewater at $400 \mathrm{~m}^{3} \mathrm{ha}^{-1}$ and 16 plots were irrigated with water and served as control. The quantity of olive mill wastewater used for the irrigation was supplied in 4 applications; a $1 / 4$ of the quantity was applied every 15 days, then we continued the irrigation by water every 15 days until harvesting. Five crops were used: tomato (Lycopersicon esculentum), chickpea (Cicer arietinum), bean (Vicia faba), wheat (Triticum durum) and barley (Hordeum vulgare). These crop species are commonly cultivated in the Mediterranean area and their culture cycles coincide with the olive mill wastewater production period. Phenological and physiological parameters such as elongation, herbage biomass, leaf number, dry weight/ fresh weight ratio, root/shoot ratio, photosynthetic activities, organic nitrogen, proteins and crop production of plants were determined.

\subsection{Physico-chemical analysis}

$\mathrm{pH}$ and electrical conductivity were determined according to Sierra et al.'s (2001) standard method. Dry weight and moisture content were determined by weighing samples before and after drying overnight at $105^{\circ} \mathrm{C}$. Organic matter was determined after drying samples in a furnace at $550{ }^{\circ} \mathrm{C}$ for $4 \mathrm{~h}$. Total organic carbon and total nitrogen were determined by dry combustion: TOC Analyser multi N/C 1000.

The chemical oxygen demand (COD) is a measure of the oxidisability of a substance, expressed as the equivalent amount in oxygen of an oxidising reagent consumed by the substance under fixed laboratory conditions. COD is an oxidisability indicator used as a practical method to measure organic matter. Chemical oxygen demand (COD) is a vital test for assessing the quality of effluents and wastewaters prior to discharge. The COD test predicts the oxygen requirement of the effluent and is used for the monitoring and control of discharges, and for assessing treatment plant performance. COD was determined according to Knechtel's (1978) standard method.

The Biochemical Oxygen Demand $\left(\mathrm{BOD}_{5}\right)$ assay is a standardised assessment of the amount of oxidisable, or respirable, organic matter in water. It is the amount of oxygen (in $\mathrm{mg} \mathrm{L}^{-1}$ ) required by bacteria to oxidise the organic molecules aerobically. Oxygen consumed by inorganic compounds is also measured by this test, which is why it is referred to as biochemical oxygen rather than just biological oxygen demand. It is used as an index of the amount of organic pollution of the water and is routinely employed to measure the efficiency of wastewater treatment plants at removing organic matter from wastewater or in assessing the effect of effluents on the trophic status of natural waters. $\mathrm{BOD}_{5}$ was determined by the manometric method with a respirometer: BSB-Controller Model $620 \mathrm{~T}$ (WTW).

The ortho-diphenol concentration in the OMW was quantified by means of the Folin-Ciocalteu colorimetric method (Box, 1983) using caffeic acid as standard. The absorbance was determined at $\lambda=765 \mathrm{~nm}$. Phosphorus, iron, magnesium, potassium, sodium and chloride were determined by atomic absorption.

\subsection{Phytotoxicity tests}

Phytotoxicity was assessed by determination of the germination index according to Zucconi et al.'s (1981) standard method.

\subsection{Soil enzymatic activities}

Urease and ammonium and nitrite oxydase activities were determined according to Kandeler et al. (1999), nitrate reductase activities were determined according to Tabatabai and $\mathrm{Fu}$ (1989), and xylanase and cellulase activities were determined according to Schinner and Von Mersi's (1990) standard methods. Enzymatic activities were expressed per gram of dried soil $\left(24 \mathrm{~h}\right.$ at $\left.105^{\circ} \mathrm{C}\right)$.

\subsection{Microbial estimation}

Ten grams of the soil sample were suspended in an Erlenmeyer flask containing $90 \mathrm{~mL}$ of a sterile solution $(0.2 \%$ of sodium polyphosphate $\left(\mathrm{NaPO}_{3}\right)_{\mathrm{n}}$ in distilled water, $\mathrm{pH}$ 7.0) and $10 \mathrm{~g}$ of sterile glass beads ( $1.5 \mathrm{~mm}$ diameter). The flask was shaken at $200 \mathrm{rpm}$ for $2 \mathrm{~h}$. Serial ten-fold dilutions of the samples in a $0.85 \% \mathrm{NaCl}$ solution were plated in triplicate on PCA at $30{ }^{\circ} \mathrm{C}$ for total bacterial counts. Ammonia and nitrite-oxidising bacteria were enumerated by the most probable number (MPN) procedure (Trolldenier, 1995). Culture tubes supplemented either with ammonium or nitrite were inoculated with serially diluted soil suspension. After an extended incubation of 4 weeks at $28^{\circ} \mathrm{C}$, acidification of the medium was recorded by taking colour change as an indication for growth of ammonium oxidisers and the absence of nitrite as an indication for growth of nitrite oxidisers. Subsequently, the most probable number was calculated in accordance with the table of MPN values. The total nitrifiers count was the sum of the oxidisers of ammonium and of nitrite.

Each soil sample was analysed in duplicate and the dilution series were plated in triplicate for each medium. All these counts were expressed as colony-forming units (CFU) per gram of dried soil $\left(24 \mathrm{~h}\right.$ at $\left.105{ }^{\circ} \mathrm{C}\right)$. The total nitrifiers count was expressed as most probable number (MPN) per gram of dried soil.

\subsection{Statistical analysis}

For each germination test, three replications were used. For plant and fruit characterisation, 4 replications were used in each 
issue. Data were analysed using the ANOVA procedure. Variance and standard deviations were determined using Genstat 5 (second edition for Windows).

\section{RESULTS AND DISCUSSION}

\subsection{Olive mill wastewater characterisation}

Olive mill wastewater (OMW) contains an enormous supply of organic matter very rich in polyphenols, which are toxic. An integrated approach was developed in our laboratory using a detoxification step of the olive mill wastewater with a whiterot fungus culture followed by anaerobic digestion in order to reuse the effluent in agriculture (Sayadi and Ellouz, 1995; Dhouib et al., 2006). The physico-chemical characteristics of the untreated olive mill wastewater and treated olive mill wastewater are summarised in Table I. As was expected, untreated olive mill wastewater was an acidic effluent which had a high nutrient content that can be used to fertilise the soil. However, it had an elevated chemical oxygen demand $(\mathrm{COD}=$ $\left.53.3 \mathrm{~g} \mathrm{~L}^{-1}\right)$ and a high phenolic content $\left(8.6 \mathrm{~g} \mathrm{~L}^{-1}\right)$, which have toxic properties.

However, treated olive mill wastewater was a slightly alkaline effluent, rich in inorganic loads such as potassium $\left(5.34 \mathrm{~g} \mathrm{~L}^{-1}\right)$, calcium (3.2 $\left.\mathrm{g} \mathrm{L}^{-1}\right)$, magnesium $\left(281 \mathrm{mg} \mathrm{L}^{-1}\right)$ and iron $\left(38.3 \mathrm{mg} \mathrm{L}^{-1}\right)$. Its content of phenolic compounds was lower

Table I. Physico-chemical characteristics of untreated olive mill wastewater $(\mathrm{U})$ and treated olive mill wastewater $(\mathrm{T})$.

\begin{tabular}{lcc}
\hline Characteristics & $\mathrm{U}$ & $\mathrm{T}$ \\
\hline $\mathrm{pH}\left(25^{\circ} \mathrm{C}\right)$ & $5 \pm 0.2$ & $8.1 \pm 0.2$ \\
Electrical conductivity $\left(25^{\circ} \mathrm{C}\right)\left(\mathrm{dS} \mathrm{m}^{-1}\right)$ & $8.2 \pm 0.1$ & $14.2 \pm 0.1$ \\
Chemical oxygen demand $\left(\mathrm{g} \mathrm{L}^{-1}\right)$ & $53.3 \pm 4.8$ & $4.5 \pm 0.41$ \\
Biochemical oxygen demand $\left(\mathrm{g} \mathrm{L}^{-1}\right)$ & $13.42 \pm 1.21$ & $1.8 \pm 0.16$ \\
$\mathrm{COD} / \mathrm{BOD}_{5}$ & $4 \pm 0.72$ & $2.5 \pm 0.45$ \\
Salinity $\left(\mathrm{g} \mathrm{L}^{-1}\right)$ & $6.23 \pm 0.56$ & $12.1 \pm 1.1$ \\
Water content $\left(\mathrm{g} \mathrm{L}^{-1}\right)$ & $960.6 \pm 19.2$ & $984 \pm 19.7$ \\
Total solids $\left(\mathrm{g} \mathrm{L}^{-1}\right)$ & $39.55 \pm 1.98$ & $15.9 \pm 0.8$ \\
Mineral matter $\left(\mathrm{g} \mathrm{L}^{-1}\right)$ & $6.5 \pm 0.33$ & $10.15 \pm 0.51$ \\
Volatile solid $\left(\mathrm{g} \mathrm{L}^{-1}\right)$ & $33 \pm 1.65$ & $4.8 \pm 0.24$ \\
Total organic carbon $\left(\mathrm{g} \mathrm{L}^{-1}\right)$ & $17.6 \pm 0.88$ & $3.2 \pm 0.16$ \\
ortho-diphenols $\left(\mathrm{g} \mathrm{L}^{-1}\right)$ & $8.6 \pm 0.86$ & $0.77 \pm 0.08$ \\
Total nitrogen $\mathrm{Kjeldhal}\left(\mathrm{g} \mathrm{L}^{-1}\right)$ & $0.5 \pm 0.05$ & $0.25 \pm 0.03$ \\
Carbon/Nitrogen & $35.2 \pm 7.04$ & $12.8 \pm 2.56$ \\
Toxicity by LUMIStox $\left(\% \mathrm{I}_{\mathrm{B}}\right)$ & $99 \pm 9$ & $30 \pm 3$ \\
$\mathrm{P}\left(\mathrm{mg} \mathrm{L}^{-1}\right)$ & $36 \pm 3.6$ & $15 \pm 1.5$ \\
$\mathrm{Na}\left(\mathrm{g} \mathrm{L}^{-1}\right)$ & $0.8 \pm 0.08$ & $0.86 \pm 0.09$ \\
$\mathrm{Cl}\left(\mathrm{g} \mathrm{L}^{-1}\right)$ & $1.45 \pm 0.15$ & $1.3 \pm 0.13$ \\
$\mathrm{~K}\left(\mathrm{~g} \mathrm{~L}^{-1}\right)$ & $8.6 \pm 0.8$ & $5.34 \pm 0.5$ \\
Ca $\left(\mathrm{g} \mathrm{L}^{-1}\right)$ & $0.9 \pm 0.09$ & $3.2 \pm 0.3$ \\
Fe (mg L & $23.4 \pm 2.3$ & $38.3 \pm 3.8$ \\
Mg (mg L & $186.9 \pm 18.7$ & $281 \pm 28.1$ \\
\hline
\end{tabular}

than $1 \mathrm{~g} \mathrm{~L}^{-1}$, reflecting a significant reduction of its toxicity from $99 \% \mathrm{I}_{\mathrm{B}}$ in untreated olive mill wastewater to only $30 \% \mathrm{I}_{\mathrm{B}}$ (Tab. I). This high content of non-toxic organic compounds, macro-elements and micro-elements indicated a significant fertilising potential of the treated olive mill wastewater that could be used advantageously in agronomy.

\subsection{Germination tests}

Seed germination was conducted both on untreated olive mill wastewater dilutions (undiluted, 1/2, 1/4, 1/10, 1/25 and $1 / 50$ ) and on treated olive mill wastewater dilutions (undiluted, $1 / 2,1 / 4$ and 1/10). The results showed that seed germination was strongly inhibited for the five studied species when untreated olive mill wastewater dilution was lower than 1/10.

For the treated olive mill wastewater diluted to $1 / 10$, positive effects on all seed germination were observed and the germination ratio was higher than in the control (Fig. 1). This is in line with previous findings. Komilis et al. (2005) showed that phytotoxicity decreased with increased OMW dilution with water. Treated olive mill wastewater did not show any inhibitory effect on seed germination and all crops presented a high germination ratio ( $>50 \%$ in all species used). Therefore, it can be suggested that the germination inhibition is principally owing to the phenolic compounds highly present in untreated olive mill wastewater (Komilis et al., 2005; Piotrowska et al., 2006). The relatively high salinity of the treated olive mill wastewater did not affect the germinability of these crops. This seems to differ from findings by Ramana et al. (2002), who reported that some crop species such as tomato, chilli, bottle gourd, cucumber and onion showed that germination (\%) decreased with increase in concentration of the highly saline effluent $\left(\mathrm{EC}=25.3 \mathrm{dS} \mathrm{m}^{-1}\right)$.

\subsection{Crop tolerance to untreated olive mill wastewater and treated olive mill wastewater during the growth and development stages}

In order to evaluate untreated olive mill wastewater and treated olive mill wastewater effects on plant growth, plant development and on crop tolerance, some agronomic tests were performed in field experiments. The same species used for the germination tests were also used for this study. Treated olive mill wastewater application did not show any morphological or physiological inhibition effect on any of the species used. Indeed, the maximum height of the treated plants was better than that of the control ones, especially for Vicia faba and Cicer arietinum. The average protein content, productivity, grain weight and the number of spikes per plant were the most sensitive yield components to the treatments and the most important for seed yield. The positive effects of the treated olive mill wastewater ferti-irrigation seemed evident, allowing optimal ripening and kernel filling. The chlorophyll a/chlorophyll b ratio and the root/shoot ratio were similar to control species values (Tab. II). The amounts of organic nitrogen and proteins in plants irrigated with treated olive mill wastewater were comparable with the control species or sometimes better, as for Hordeum vulgare and Cicer arietinum (Tab. III). Indeed, the lower amount of phenolic compounds in treated olive mill wastewater $\left(0.77 \mathrm{~g} \mathrm{~L}^{-1}\right)$ had no harmful effect on the photosynthetic plant 
Germination Index (\%)

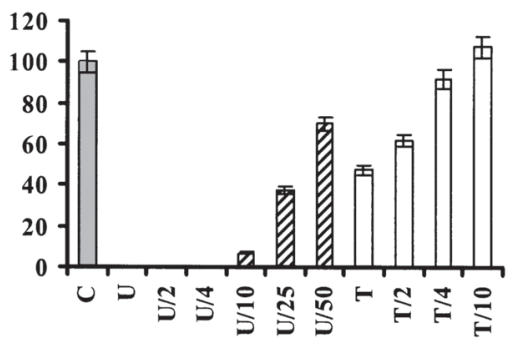

Germination Index (\%)

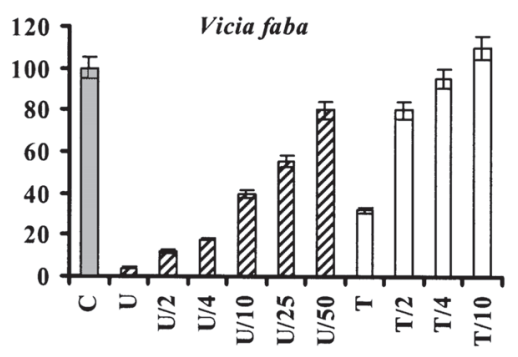

Germination Index (\%)

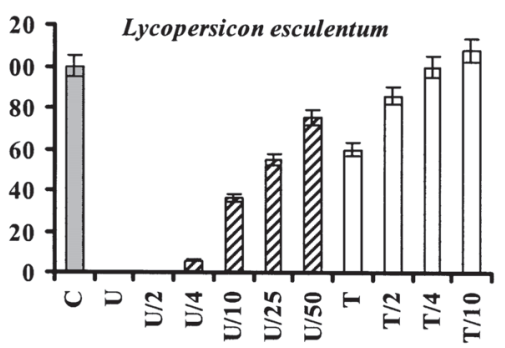

Germination Index (\%)

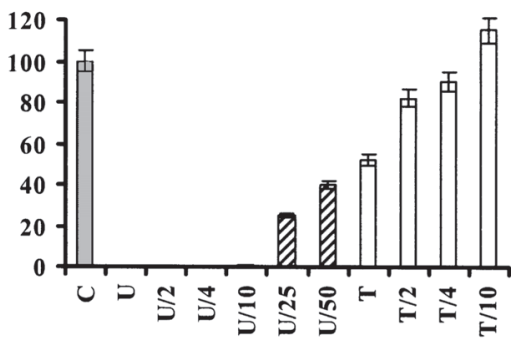

Germination Index (\%)

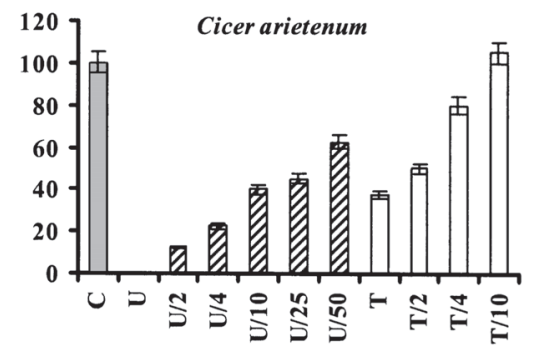

Germination Index (\%)

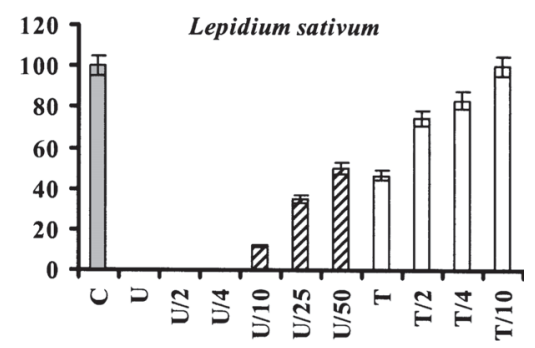

Figure 1. Germination Index of Triticum durum, Hordeum vulgare, Lycopersicon esculentum, Cicer arietinum, Vicia faba and Lepidium sativum determined on distilled water as control (C), untreated olive mill wastewater (U) and treated olive mill wastewater (T). (number under the slash indicates the dilution factor).

activities, and nitrogen assimilation was not inhibited. Table III shows an improvement in seed biomass, spike number, plant growth and a similar or even better dry productivity than plants irrigated with water (Hordeum vulgare $102 \%$, Triticum durum $105 \%$, Cicer arietinum $101 \%$ and Vicia faba $102 \%$ of control).

On the contrary, there was a negative effect of the untreated olive mill wastewater causing an inhibitory effect on the growth of all species used. Indeed, a significant reduction of the plant height, the number of leaves and branches and the (fresh weight/dry weight) ratio were noted comparatively with the control species (Fig. 2). This is probably due to its high concentration in phenolics, which causes leaf necrosis. Besides, it inhibits photosynthesis, which unbalances the protein content and productivity of the plant. However, plants irrigated with untreated olive mill wastewater showed lower dry productivity in comparison with control species (Hordeum vulgare 40\%, Triticum durum $53.5 \%$, Cicer arietinum $79 \%$ and Vicia faba $83.5 \%$ of control). Triticum durum exhibited the best dry productivity, and Hordeum vulgare and Cicer arietinum exhibited in addition a higher protein content when they were irrigated with treated olive mill wastewater. Therefore, it can be concluded that these species constitute suitable crops that can be irrigated with treated olive mill wastewater.

Plants irrigated with untreated olive mill wastewater showed a significant reduction of contents of chlorophyll a and chlorophyll b. The (chlorophyll a/chlorophyll b) ratio was significantly different from control plants and consequently, leaf chlorosis was observed. The (root/shoot) ratio in plants irrigated with untreated olive mill wastewater was also different from control plants (Tab. II). This finding confirms previous findings by Paredes et al. (1999) reporting that OMW application has negative effects such as the immobilisation of available nitrogen, the displacement of the exchange complex and the decrease in plant-available magnesium. Also, in line with this, Piotrowska et al. (2006) observed that soil became highly phytotoxic after addition of olive mill wastewater; Rinaldi et al. (2003) showed that crude olive mill wastewater has phytotoxic effects on barley, durum and soft wheat.

\subsection{Soil fertilisation}

Physico-chemical composition, total mesophilic microflora, nitrifiers, principal enzymatic activities and respiration potential 
Table II. Fresh biomass and chlorophyll content of the plant species ferti-irrigated with water as control (C), with untreated olive mill wastewater $(\mathrm{U})$ and with treated olive mill wastewater $(\mathrm{T})$.

Chl.a: chlorophyll a; Chl.b: chlorophyll b.

\begin{tabular}{|c|c|c|c|c|c|c|c|}
\hline & & $\begin{array}{l}\text { Shoot } \\
\text { (g) }\end{array}$ & $\begin{array}{l}\text { Root } \\
\text { (g) }\end{array}$ & $\begin{array}{l}\text { Root/Shoot } \\
\text { ratio }\end{array}$ & $\begin{array}{c}\text { Chl.a } \\
\left(\mathrm{mg} \mathrm{g}^{-1}\right)\end{array}$ & $\begin{array}{l}\text { Chl.b } \\
\left(\mathrm{mg} \mathrm{g}^{-1}\right)\end{array}$ & $\begin{array}{c}\text { Chl.a/Chl.b } \\
\text { ratio }\end{array}$ \\
\hline \multirow{3}{*}{$\begin{array}{l}\text { Hordeum } \\
\text { Vulgare }\end{array}$} & $\mathrm{C}$ & $2.44 \pm 0.5$ & $0.18 \pm 0.02$ & $0.07 \pm 0.005$ & $0.63 \pm 0.07$ & $0.42 \pm 0.04$ & $1.5 \pm 0.11$ \\
\hline & $\mathrm{U}$ & $1.08 \pm 0.22$ & $0.47 \pm 0.08$ & $0.43 \pm 0.03$ & $0.05 \pm 0.01$ & $0.01 \pm 0.00$ & $5.0 \pm 0.38$ \\
\hline & $\mathrm{T}$ & $1.9 \pm 0.27$ & $0.05 \pm 0.01$ & $0.02 \pm 0.001$ & $0.08 \pm 0.01$ & $0.06 \pm 0.01$ & $1.33 \pm 0.1$ \\
\hline \multirow[t]{3}{*}{ Triticum durum } & $\mathrm{C}$ & $1.35 \pm 0.33$ & $0.18 \pm 0.03$ & $0.13 \pm 0.01$ & $0.02 \pm 0.00$ & $0.03 \pm 0.00$ & $0.66 \pm 0.05$ \\
\hline & $\mathrm{U}$ & $0.93 \pm 0.07$ & $0.18 \pm 0.05$ & $0.19 \pm 0.015$ & $0.01 \pm 0.00$ & $0.002 \pm 0.00$ & $5.0 \pm 0.38$ \\
\hline & $\mathrm{T}$ & $1.63 \pm 0.12$ & $0.09 \pm 0.01$ & $0.05 \pm 0.003$ & $0.06 \pm 0.01$ & $0.05 \pm 0.01$ & $1.20 \pm 0.09$ \\
\hline \multirow{3}{*}{$\begin{array}{l}\text { Cicer } \\
\text { arietinum }\end{array}$} & $\mathrm{C}$ & $6.05 \pm 0.65$ & $1.02 \pm 0.12$ & $0.17 \pm 0.013$ & $0.05 \pm 0.01$ & $0.04 \pm 0.01$ & $1.25 \pm 0.1$ \\
\hline & $\mathrm{U}$ & $1.53 \pm 0.15$ & $0.27 \pm 0.09$ & $0.018 \pm 0.001$ & $0.01 \pm 0.00$ & $0.02 \pm 0.01$ & $0.50 \pm 0.04$ \\
\hline & $\mathrm{T}$ & $2.6 \pm 0.38$ & $0.42 \pm 0.13$ & $0.16 \pm 0.012$ & $0.07 \pm 0.01$ & $0.06 \pm 0.01$ & $1.16 \pm 0.09$ \\
\hline \multirow{3}{*}{$\begin{array}{l}\text { Vicia } \\
\text { faba }\end{array}$} & $\mathrm{C}$ & $36 \pm 2.7$ & $4.6 \pm 0.7$ & $0.12 \pm 0.01$ & $0.13 \pm 0.05$ & $0.09 \pm 0.03$ & $1.44 \pm 0.11$ \\
\hline & $\mathrm{U}$ & $23.5 \pm 1.6$ & $8.7 \pm 1.2$ & $0.37 \pm 0.03$ & $0.07 \pm 0.03$ & $0.09 \pm 0.03$ & $0.77 \pm 0.06$ \\
\hline & $\mathrm{T}$ & $27.5 \pm 1.9$ & $3.4 \pm 0.45$ & $0.12 \pm 0.01$ & $0.61 \pm 0.12$ & $0.35 \pm 0.08$ & $1.74 \pm 0.13$ \\
\hline
\end{tabular}

Table III. Main yield components, spike number and weight, proteins and productivity \pm standard deviations of different plant species grown on soil ferti-irrigated with water $(\mathrm{C})$, untreated olive mill wastewater $(\mathrm{U})$ and treated olive mill wastewater $(\mathrm{T})$.

\begin{tabular}{|c|c|c|c|c|}
\hline Plant species & Parameters & $\mathrm{C}$ & $\mathrm{U}$ & $\mathrm{T}$ \\
\hline \multirow{5}{*}{ Hordeum vulgare } & Spike number/plant & $6 \pm 1$ & $2 \pm 0.9$ & $6.05 \pm 0.8$ \\
\hline & Spike fresh weight (g) & $2.5 \pm 0.09$ & $1.3 \pm 0.05$ & $2.9 \pm 0.07$ \\
\hline & Proteins $\left(\mathrm{mg} \mathrm{g}^{-1}\right)$ & $9.8 \pm 0.13$ & $7.1 \pm 0.08$ & $16.4 \pm 0.17$ \\
\hline & Fresh productivity $\left(\mathrm{kg} \mathrm{ha}^{-1}\right)$ & $2620 \pm 15$ & $1020 \pm 9$ & $2680 \pm 5$ \\
\hline & Dry productivity $\left(\mathrm{kg} \mathrm{ha}^{-1}\right)$ & $1360 \pm 7$ & $550 \pm 13$ & $1390 \pm 8$ \\
\hline \multirow{5}{*}{ Triticum durum } & Spike number/plant & $9 \pm 0.9$ & $5 \pm 0.7$ & $10 \pm 1$ \\
\hline & Spike fresh weight (g) & $1 \pm 0.03$ & $1 \pm 0.01$ & $1.2 \pm 0.01$ \\
\hline & Proteins $\left(\mathrm{mg} \mathrm{g}^{-1}\right)$ & $6.9 \pm 0.04$ & $10 \pm 0.09$ & $8.1 \pm 0.01$ \\
\hline & Fresh productivity $\left(\mathrm{kg} \mathrm{ha}^{-1}\right)$ & $3400 \pm 70$ & $1620 \pm 14$ & $3520 \pm 70$ \\
\hline & Dry productivity $\left(\mathrm{kg} \mathrm{ha}^{-1}\right)$ & $1270 \pm 7$ & $680 \pm 3$ & $1340 \pm 7$ \\
\hline \multirow{5}{*}{ Cicer arietinum } & Seed number/plant & $17 \pm 0.9$ & $12 \pm 0.7$ & $18 \pm 0.9$ \\
\hline & Seed fresh weight (g) & $1.1 \pm 0.01$ & $0.9 \pm 0.01$ & $1.1 \pm 0.01$ \\
\hline & Proteins $\left(\mathrm{mg} \mathrm{g}^{-1}\right)$ & $3.8 \pm 0.06$ & $17.25 \pm 0.03$ & $10.9 \pm 0.02$ \\
\hline & Fresh productivity $\left(\mathrm{kg} \mathrm{ha}^{-1}\right)$ & $5370 \pm 10$ & $4240 \pm 15$ & $5630 \pm 9$ \\
\hline & Dry productivity $\left(\mathrm{kg} \mathrm{ha}^{-1}\right)$ & $3580 \pm 15$ & $2830 \pm 12$ & $3620 \pm 15$ \\
\hline \multirow{5}{*}{ Vicia faba } & Pod number/plant & $7 \pm 0.7$ & $4 \pm 0.6$ & $6 \pm 0.7$ \\
\hline & Pod fresh weight (g) & $12.7 \pm 0.07$ & $5.8 \pm 0.03$ & $11.6 \pm 0.09$ \\
\hline & Proteins $\left(\mathrm{mg} \mathrm{g}^{-1}\right)$ & $41.4 \pm 0.07$ & $18.8 \pm 0.03$ & $20.7 \pm 0.04$ \\
\hline & Fresh productivity $\left(\mathrm{kg} \mathrm{ha}^{-1}\right)$ & $6000 \pm 17$ & $3660 \pm 7$ & $7020 \pm 20$ \\
\hline & Dry productivity $\left(\mathrm{kg} \mathrm{ha}^{-1}\right)$ & $4430 \pm 9$ & $3700 \pm 7$ & $4510 \pm 9$ \\
\hline
\end{tabular}


maximum height $(\mathbf{c m})$

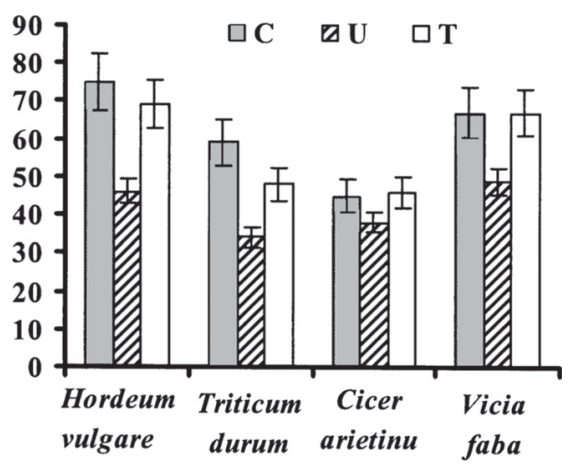

Figure 2. Maximum heights of Hordeum vulgare, Triticum durum Cicer arietinum and Vicia faba ferti-irrigated with treated olive mill wastewater (T), untreated olive mill wastewater (U) and water (C).

were evaluated in ferti-irrigated soil with olive mill wastewater and compared with control soil. $\mathrm{pH}$ in the control soil was 8.4. However, in soil ferti-irrigated with treated olive mill wastewater, this value increased to 8.9 and never decreased. $\mathrm{pH}$ decreased to 8.26 in soil ferti-irrigated with untreated olive mill wastewater. The soil salinity increase was more pronounced in treated olive mill wastewater-irrigated soil than in untreated olive mill wastewater-irrigated soil.

Morphological differences between the control soil and the untreated olive mill wastewater-irrigated soil were also observed.
Indeed, the soil colour was darker after untreated olive mill wastewater application. Moreover, the soil became more compact, suggesting that the untreated olive mill wastewater can lead to impairment in the soil aeration. The organic matter pool was enhanced, but the respiration potential, total mesophilic and nitrifier microflora were inhibited, as was shown in previous studies (Mekki et al., 2006). Untreated olive mill wastewater-irrigated soil also showed a significant inhibition of some enzymatic activities such as urease and ammonium oxydase activities (Tab. IV). Piotrowska et al. (2006) observed a rapid increase in dehydrogenase and urease activities.

On the other hand, treated olive mill wastewater-irrigated soil showed an increase in its organic matter content. In addition, its respiration potential was improved, as was suggested by Komilis et al. (2005) and Mekki et al. (2006) and there was a significant increase in its nitrifier microflora. Besides, it had a similar $\mathrm{C} / \mathrm{N}$ ratio to that of the control soil. Its enzymatic activities such as urease, nitrate reductase, ammonium oxydase, xylanase and cellulase were enhanced (Tab. IV).

\section{CONCLUSION}

Olive mill wastewaters constitute a serious environmental problem. Several physico-chemical and biological processes to reduce their contaminant impacts have been proposed. Many researchers have established that these wastewaters have a high fertiliser value when applied to the soil. Soils in semi-arid and arid areas are known to have low organic matter levels, a low

Table IV. Physico-chemical and biological characteristics of soil ferti-irrigated with water as control (C), with untreated olive mill wastewater (U) and with treated olive mill wastewater (T).

CFU: colony-forming unit; GE: glucose equivalent; MPN: most probable number; $\mathrm{NH}_{4}-\mathrm{N}$ : ammonium nitrogen; $\mathrm{NO}_{2}-\mathrm{N}$ : nitrate nitrogen; w/w: weight/weight.

\begin{tabular}{|c|c|c|c|}
\hline Soil characteristics & $\mathrm{C}$ & $\mathrm{U}$ & $\mathrm{T}$ \\
\hline $\mathrm{pH}\left(21^{\circ} \mathrm{C}\right)$ & $8.4 \pm 0.2$ & $8.26 \pm 0.2$ & $8.9 \pm 0.2$ \\
\hline Electrical conductivity $\left(25^{\circ} \mathrm{C}\right)\left(\mathrm{dS} \mathrm{m}{ }^{-1}\right)$ & $0.2 \pm 0.1$ & $0.5 \pm 0.1$ & $0.7 \pm 0.1$ \\
\hline Salinity $\left(\mathrm{mg} \mathrm{kg}^{-1}\right)$ & $151.7 \pm 13.65$ & $351.5 \pm 31.63$ & $505.5 \pm 45.5$ \\
\hline Moisture content $\left(\mathrm{mg} \mathrm{kg}^{-1}\right)$ & $17 \pm 0.35$ & $18.1 \pm 0.36$ & $28.3 \pm 0.57$ \\
\hline Dry weight $(\%)(\mathrm{w} / \mathrm{w})$ & $98.3 \pm 2$ & $98.2 \pm 2$ & $97.2 \pm 1.9$ \\
\hline Organic matter $(\%)(w / w)$ & $1.8 \pm 0.18$ & $4.5 \pm 0.45$ & $2.9 \pm 0.29$ \\
\hline Mineral matter $(\%)(w / w)$ & $96.5 \pm 9.7$ & $93.7 \pm 9.4$ & $94.3 \pm 9.4$ \\
\hline Total organic carbon $(\%)(w / w)$ & $1.04 \pm 0.01$ & $2.61 \pm 0.26$ & $1.66 \pm 0.17$ \\
\hline Total nitrogen Kjeldhal (\%) (w/w) & $0.1 \pm 0.01$ & $0.12 \pm 0.01$ & $0.16 \pm 0.02$ \\
\hline Carbon/Nitrogen & $10.4 \pm 2.1$ & $21.75 \pm 4.35$ & $10.37 \pm 2.1$ \\
\hline Aerobic heterotrophic bacteria counts $\left(10^{6} \mathrm{CFU} \mathrm{g}{ }^{-1}\right)$ & $58 \pm 6$ & $60 \pm 6$ & $71 \pm 7$ \\
\hline Nitrifier counts $\left(10^{2} \mathrm{MPN} \mathrm{g}^{-1}\right)$ & $1.4 \pm 0.14$ & $0.8 \pm 0.08$ & $22 \pm 2.2$ \\
\hline Urease $\left(\mu \mathrm{g} \mathrm{NH} \mathrm{NH}_{4}-\mathrm{N} \mathrm{g}^{-1} 2 \mathrm{~h}^{-1}\right)$ & $42 \pm 0.42$ & $38 \pm 0.38$ & $112 \pm 11.2$ \\
\hline Nitrate reductase $\left(\mu \mathrm{g} \mathrm{NO}_{2}-\mathrm{N} \mathrm{g}^{-1} 24 \mathrm{~h}^{-1}\right)$ & $0.53 \pm 0.053$ & $1.42 \pm 0.14$ & $1.18 \pm 0.12$ \\
\hline Ammonium oxidase $\left(\mu \mathrm{g} \mathrm{NO}_{2}-\mathrm{N} \mathrm{g}^{-1} 24 \mathrm{~h}^{-1}\right)$ & $0.24 \pm 0.02$ & $0.17 \pm 0.02$ & $0.71 \pm 0.07$ \\
\hline Xylanase $\left(\mu \mathrm{g} \mathrm{GE} \mathrm{g} \mathrm{g}^{-1} 24 \mathrm{~h}^{-1}\right)$ & $34.6 \pm 3.5$ & $106.5 \pm 10.7$ & $124.5 \pm 12.5$ \\
\hline 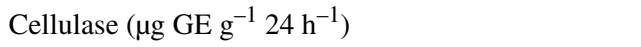 & $21.7 \pm 2.2$ & $26.8 \pm 2.7$ & $58.4 \pm 5.8$ \\
\hline
\end{tabular}


fertility and a high exposure to degradation, desertification and pollution. Currently, organic wastes of various origins and nature are widely used as amendments to increase soil organic matter and crop productivity. Olive mill wastewater treated with white-rot fungi followed by anaerobic digestion still contains relatively high amounts of dissolved and suspended organic matter in a large volume of water and could be a potential candidate for use as a liquid organic amendment, especially for soils and crops. This effluent has a very small amount of phenolic compounds and a significant amount of fertilising elements such as $\mathrm{P}, \mathrm{K}, \mathrm{Mg}$ and $\mathrm{Fe}$. Its application in crop irrigation showed very encouraging results which may make its use in agriculture a potential solution for olive mill wastewater management and valorisation. Nevertheless, the application of olive mill wastewater without pre-treatment had negative affects on soil structure and composition and inhibited seed germination and plant growth.

Acknowledgments: This research was supported by the E.C. program "Medusa water" contract ICA-CT-1999-00010 and contract programmes (MRSTDC, Tunisia).

\section{REFERENCES}

Box J.D. (1983) Investigation of the Folin-ciocalteau phenol reagent for the determination of polyphenolic substances in natural waters, Water Res. 17, 511-522.

Capasso R., Cristinzio G., Evidente A., Scognamiglio F. (1992) Isolation, spectroscopy and selective phytotoxic effects of polyphenols from vegetable waste waters, Phytochem. 31, 4125-4128.

Casa R., D’Annibale A., Pieruccetti F., Stazi S.R., Giovannozzi Sermanni G., Lo Cascio B. (2003) Reduction of the phenolic components in olive-mill wastewater by an enzymatic treatment and its impact on durum wheat (Triticum durum Desf.) germinability, Chemosphere 50, 959-966.

Cereti C.F., Rossini F., Federici F., Quaratino D., Vassilev N., Fenice M. (2004) Reuse of microbially treated olive mill wastewater as fertiliser for wheat (Triticum durum Desf.), Bioresource Technol. 91, $135-140$.

Cox L., Celis R., Hermosin M.C., Beker A., Cornejo J. (1998) Porosity and herbicide leaching in soils amended with olive-mill wastewater, Agr. Ecosyst. Environ. 65, 151-161.

Dagnelie (2003) La notion d'unité expérimentale, in: Principes d'expérimentations : planifications des expériences et analyse de leurs résultats, Les presses agronomiques de Gembloux, septembre 2003, pp. 76-81.

D’Annibale A., Casa R., Pieruccetti F., Ricci M., Marabottini R. (2004) Lentinula edodes removes phenols from olive-mill wastewater: impact on durum wheat (Triticum durum Desf.) germinability, Chemosphere 54, 887-894.

Dhouib A., Aloui F., Hamad N., Sayadi S. (2006) Pilot-plant treatment of olive mill wastewaters by Phanerochaete chrysosporium coupled to anaerobic digestion and ultrafiltration, Process Biochem. 41, 159-167.

Feria L.A. (2000) The generated situation by the O.M.W. in Andalusia, Actas/Proceedings-Workshop Improlive-2000-Anexo A1/Annex A1, pp. 55-63.

Hytiris N., Kapellakis I.E., La Roij R., Tsagarakis K.P. (2004) The potential use of olive mill sludge in solidification process, Resour. Conserv. Recycl. 40, 129-139.
Kandeler E., Stemmer M., Klimanek E.M. (1999) Response of soil microbial biomass, urease and xylanase within particle size fractions to long-term soil management, Soil Biol. Biochem. 31, 261273 .

Knechtel R.J. (1978) A more economical method for the determination of chemical oxygen demand, Water Pollut. Control. (May/June), 25-29.

Komilis D.P., Karatzas E., Halvadakis C.P. (2005) The effect of olive mill wastewater on seed germination after various pretreatment techniques, J. Environ. Manage. 74, 339-348.

Mekki A., Dhouib A., Sayadi S. (2006) Changes in microbial and soil properties following amendment with treated and untreated olive mill wastewater, Microbiol. Res. (in press).

Moreno E., Perez J., Ramos-Cormenzana A., Martinez J. (1987) Antimicrobial effect of waste water from olive oil extraction plants selecting soil bacteria after incubation with diluted waste, Microbios. 51, 169-174.

Paredes C., Cegarra J., Roig A., Sanchez-Monedero M.A., Bernal M.P. (1999) Characterisation of olive mill wastewater (alpechin) and its sludge for agricultural purposes, Bioresource Technol. 67, 111115 .

Paredes C., Cegarra J., Bernal M.P., Roig A. (2005) Influence of olive mill wastewater in composting and impact of the compost on a Swiss chard crop and soil properties, Environ. Int. 31, 305-312.

Piotrowska A., Iamarino G., Rao M.A., Gianfreda L. (2006) Short-term effects of olive mill waste water (OMW) on chemical and biochemical properties of a semiarid Mediterranean soil, Soil Biol. Biochem. (in press).

Ramana S., Biswas A.K., Kundu S., Saha J.K., Yadava R.B.R. (2002) Effect of distillery effluent on seed germination in some vegetable crops, Bioresource Technol. 82, 273-275.

Rana G., Rinaldi M., Introna M. (2003) Volatilisation of substances after spreading olive oil waste water on the soil in a Mediterranean environment, Agr. Ecosyst. Environ. 96, 49-58.

Rinaldi M., Rana G., Introna M. (2003) Olive-mill wastewater spreading in southern Italy: effects on a durum wheat crop, Field Crops Res. 84, 319-326.

Sayadi S., Ellouz R. (1995) Roles of lignin peroxidase and manganese peroxidase from Phanerochaete chrysosporium in the decolorization of olive mill wastewaters, Appl. Environ. Microbiol. 61, 1098-1103.

Sayadi S., Allouch N., Jaoua M., Aloui F. (2000) Detrimental effects of high molecular-mass polyphenols on olive mill wastewaters biotreatments, Process Biochem. 35, 725-735.

Schinner F., Von Mersi W. (1990) Xylanase-CM-cellulase- and invertase activity in soil: an improved method, Soil Biol. Biochem. 22, 511-515.

Sierra J., Marti E., Montserrat G., Cruanas R., Garau M.A. (2001) Characterization and evolution of a soil affected by olive oil mill wastewater disposal, Sci. Total Environ. 279, 207-214.

Tabatabai M.A., Fu M.H. (1989) Nitrate reductase activity in soils: effects of trace elements, Soil Biol. Biochem. 21, 943-946.

Trolldenier G. (1995) Nitrifiers by MPN method, in: Schinner F., Öhlinger R., Kandeler E., Margesin R. (Eds.), Methods in soil biology, Springer, Berlin, pp. 32-36.

Vassilev N., Vassilev M., Azcon R., Fenice M., Federici F., Barea J.M. (1998) Fertilizing effect of microbially treated olive mill wastewater on Trifolium plants, Bioresour. Technol. 66, 133-137.

Zucconi F., Forte M., Monac A., Beritodi M. (1981) Biological evaluation of compost maturity, Biocycle 22, 27-29. 